\title{
1. Convergence? More developing countries are catching up
}

Vladimir Popov and Jomo Kwame Sundaram*

Normally, the literature on convergence and divergence in the world economy looks at beta-convergence and sigma-convergence. The former (beta-convergence) focuses on the coefficient of per capita GDP in the regression equation for growth rates - if positive, it means poorer countries are growing more slowly than the rich, and divergence is taking place; a negative coefficient means that growth is higher in poorer countries, which are therefore converging with the rich countries. The latter (sigma-convergence) looks at the standard deviation of the average per capita income of different countries from the world average - if it is increasing, national per capita incomes are diverging from the world average, whereas a decrease signifies convergence (see Maurer, 1995 for a survey).

We propose a more nuanced, substantial and less statistical approach to show that while some developing countries are converging with the rich countries, most others are not, with many falling behind. We accept Amsden's (2011) definition of the 'Rest' and her distinction between different trajectories of development - independent (East and South Asia) and integrationist (Latin America). In 1500, the ratio of average per capita income in the West (Western Europe) and the Rest (all other countries) was approximately 1:1. By 1900, the ratio of average per capita incomes in the West (Western Europe and its former settler colonies in North America and Australasia) and the global South (developing countries) had increased to 6:1, and remained around that level for the next century. If China is excluded, the ratio of average per capita incomes in rich countries and poor countries has actually increased, but not as quickly as in the past (Wade, 2004) (Figures 1.1 and 1.2).

In the second half of the twentieth century, however, examples of successful catch-up development grew. Japan, Hong Kong, Singapore,

\footnotetext{
* The views expressed are those of the authors and not necessarily those of their respective organizations. We are grateful to Anis Chowdhury, Piotr Dutkiewicz and Alex Trepelkov for important comments and discussion. The usual disclaimers apply.
} 


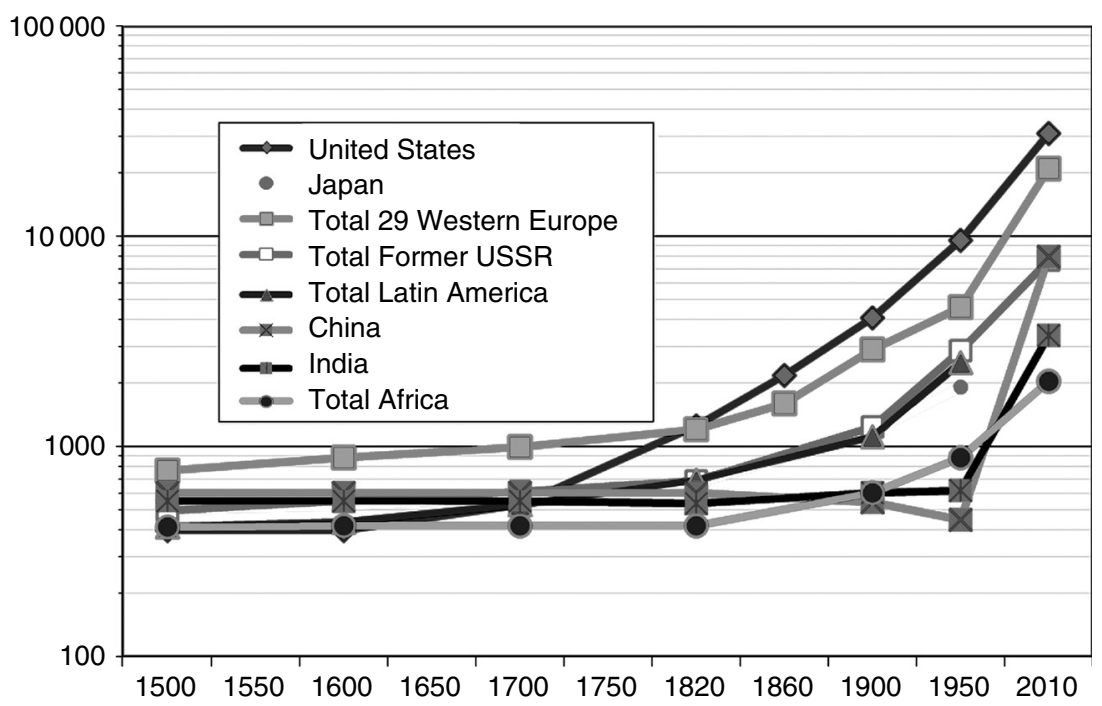

Source: Maddison Project (2013).

Figure 1.1 Purchasing power parity gross domestic product (PPP GDP) per capita in major countries and regions since $1500(1990$ international Geary-Khamis dollars, log scale)

Taiwan and South Korea (in chronological order) were the only states/ territories that successfully caught up with the West to become developed countries during 1950-90. In recent decades, growth has accelerated in Southeast Asia (Sundaram et al., 1997) and China (Lin, 2012). Together with the recent acceleration of growth in India, Bangladesh and some other developing countries, this seems to signify a partial end to the Great Divergence (Nayyar, 2013; WESS, 2010). It may well be that in the twenty-first century, the world will experience a gradual global convergence in income levels, with the gap between the North and the South narrowing (Figures 1.1 and 1.2).

Other regions of the global South (especially sub-Saharan Africa, as well as Eastern Europe and the former Soviet Union) have not been catching up, with some even falling behind, especially in the 1980s and 1990s, during the heyday of the Washington Consensus (Ocampo et al., 2007). But for the first time in half a millennium, the average gap in per capita GDP has stopped widening, and started to close for several major economies.

Measures of global income inequality also point to slowing economic divergence in the second half of the twentieth century and even reversal of 


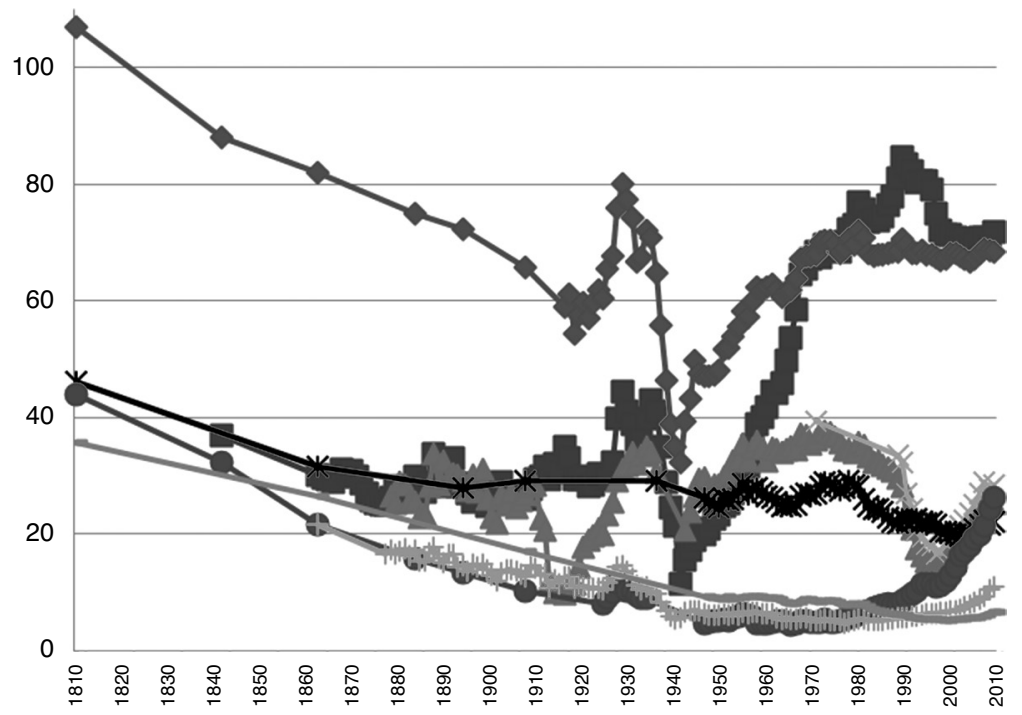

\begin{tabular}{ll}
$\rightarrow-$ Japan & $*$ Latin America \\
$\rightarrow$ Western Europe & $\rightarrow$ China \\
$\leftarrow$ FSU & + India \\
$\leftarrow$ Russia & - Africa \\
\hline
\end{tabular}

Note: FSU $=$ Former Soviet Union.

Source: Maddison Project (2013).

Figure 1.2 PPP GDP per capita (in 1990 international Geary-Khamis dollars) as a percentage of US level

the trend with African and Asian decolonization after the Second World War. Inequalities among countries, if measured by weighting the average national incomes of countries by population size, clearly increased during 1820-1950, before falling thereafter. Even if China is excluded, the disparity between the global North and South did not rise significantly after 1950 , as it had before. It remained stable during 1950-80, increased during 1980-2000 and fell afterwards (Milanovic, 2009).

Between-country disparities have started to decline since 2000, reversing the previous divergence in national income levels (WESS, 2014).

Why has the income gap between the West and the Rest, growing for nearly half a millennium, started to close? Is it temporary or enduring? 


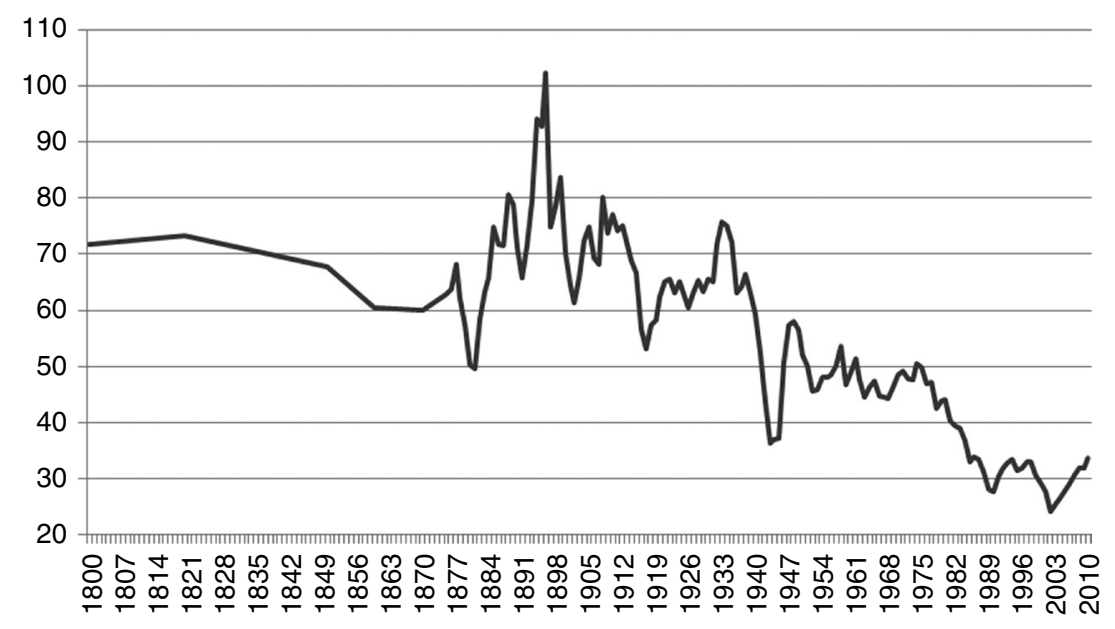

Source: Maddison Project (2013).

Figure 1.3 PPP GDP per capita in Argentina as a percentage of US level, 1800-2010

To answer these questions, we first consider several attempts at catch-up development in the twentieth century (Popov, 2014).

\section{TWENTIETH-CENTURY CATCH-UP ATTEMPTS}

There have been cases of losing rich country status, with the most prominent being Argentina in the twentieth century (Figure 1.3). But most countries that first industrialized in the eighteenth and nineteenth centuries (the West) have stayed rich, whereas the Rest stayed relatively poor, with per capita incomes below half the level of the West, until the mid-twentieth century.

From the 1930s to the 1960s, the USSR was the first major non-Western country to achieve successful catch-up development, narrowing its income gap with the West. However, in the 1970s and 1980s, the gap ceased to narrow, before widening dramatically in the early 1990s. Soviet catch-up development was clearly impressive until the 1970s. Russia had steadily fallen behind the West from the sixteenth to the nineteenth centuries, notwithstanding the much celebrated reforms of Peter the Great in the early eighteenth century, the elimination of serfdom in 1861 (Emancipation Act), as well as Witte's and Stolypin's reforms in the early twentieth century. However, for the first time in its history, Russia (USSR) started to 


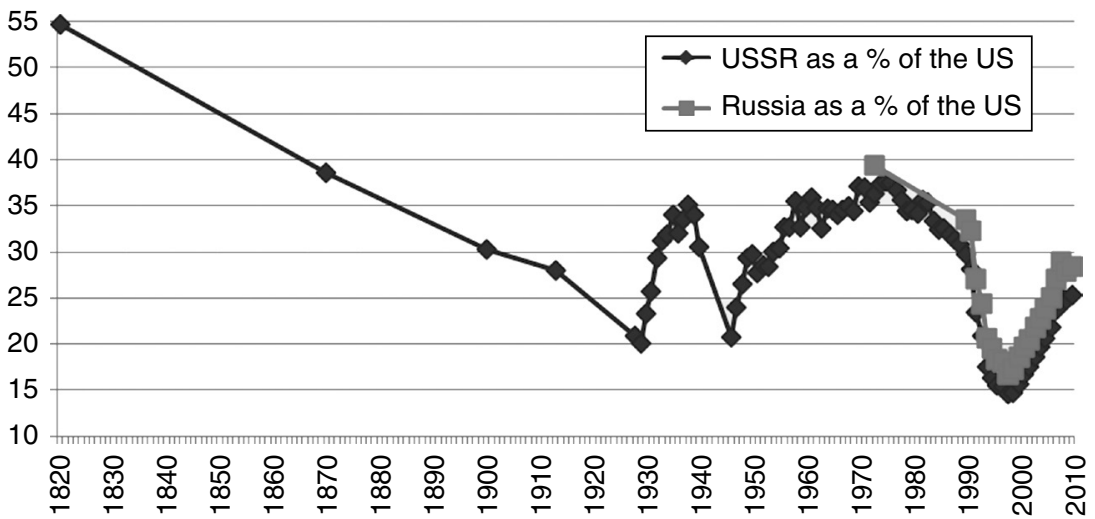

Source: Maddison Project (2013).

Figure 1.4 PPP GDP per capita in the USSR and Russia as a percentage of US level, 1820-2010

catch up with the West from the 1920s to the 1960s (Figure 1.4). In fact, until the 1960s, the USSR and Japan were the only two major countries that successfully closed their gaps with the West (Figure 1.2).

Although labor productivity growth rates in the 1930s were high (3 percent yearly), they were not exceptional unlike the higher rates observed in the 1950s (6 percent annually) (Figure 1.5) (Popov, 2007). Total factor productivity (TFP) growth rates increased from 0.6 percent annually in the 1930 s to 2.8 percent in the 1950 s before falling, even becoming negative, in the 1980s (Table 1.1). The 1950s was thus the 'golden period' of Soviet economic growth (Figure 1.6). Soviet growth in the 1950s was comparable to Japanese growth from the 1950s to the 1970s as well as Korean and Taiwanese growth during 1960-90; in Solovian growth accounting terms, rapid increases in labor productivity greatly offset declining capital productivity, so TFP increased (Table 1.1). But rapid Soviet economic growth was not sustained for even two decades (Figures 1.4 and 1.5), whereas it continued for three to four decades in East Asia, propelling Japan, South Korea and Taiwan into the ranks of developed countries.

Among the many reasons for the slowing Soviet growth rate from the 1960 s to the 1980 s, the most crucial appears to have been the 'computation problem' - the inability of a centrally planned economy to efficiently balance the supply and demand of millions of goods and services. This led to inadequate investments to replace retired fixed capital stock (Popov, 2007, 2014). As the task of renovating physical capital contradicted the short-term goal of fulfilling planned targets, Soviet planners preferred to 


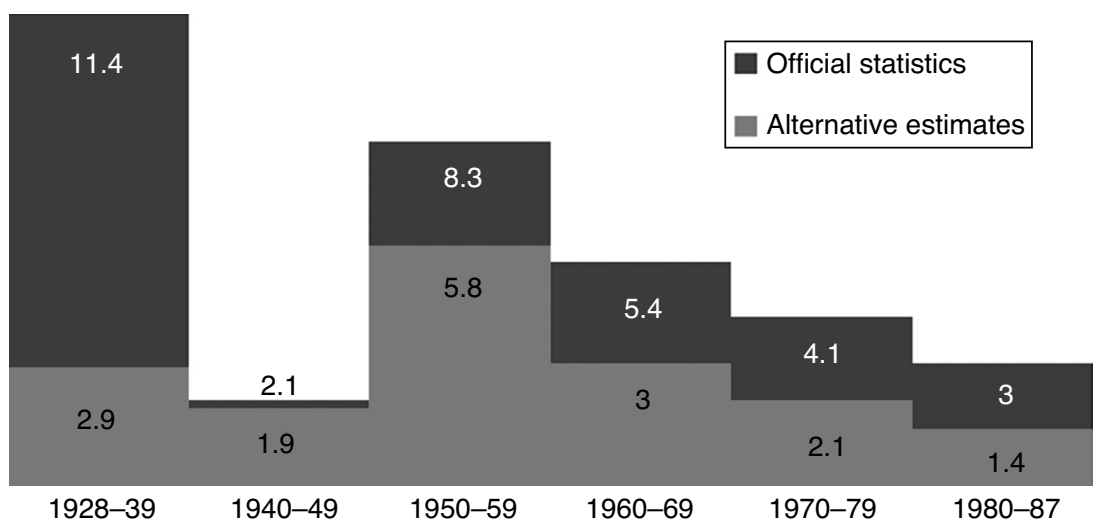

Source: Easterly and Fisher (1995).

Figure 1.5 Annual labor productivity growth rates in the Soviet economy, $1928-87(\%)$

invest in new capacities instead of upgrading existing ones. Hence, after the massive investment of the 1930s during the Big Push, the highest productivity was achieved during the service life of the capital stock (averaging about 20 years) before the need for massive investment to replace retired stock emerged. Consequently, capital stock started to age rapidly, sharply reducing capital productivity and lowering labor productivity and the TFP growth rate. In retrospect, the relatively limited Chinese experience with central planning in the 1950s to 1970s before the transition to the market in the 1980s avoided such problems associated with the longer Soviet experience (1929-91). It is possible that a transition to a market economy in the Soviet Union would have been more successful if it had started in the 1960s (Popov, 2007).

Some countries in Latin America, Africa and the Middle East experienced growth spurts and seemed to be catching up with the West in the course of the second half of the twentieth century, but most of these growth spurts did not last. From the 1950s to the 1970s, many developing countries in Latin America and Africa experienced relatively fast growth, but most lost momentum after the debt crises of the early 1980s. Economists wrote about a 'lost decade' in Latin America (1980s) and longer stagnation in Africa (1980s, 1990s). The trajectory of Brazil (Figure 1.6), which experienced a half century of rapid growth before the 1980 s, was arguably typical in this respect.

The first really successful catch-up in East Asia occurred after the Second World War - with five countries/territories having per capita 


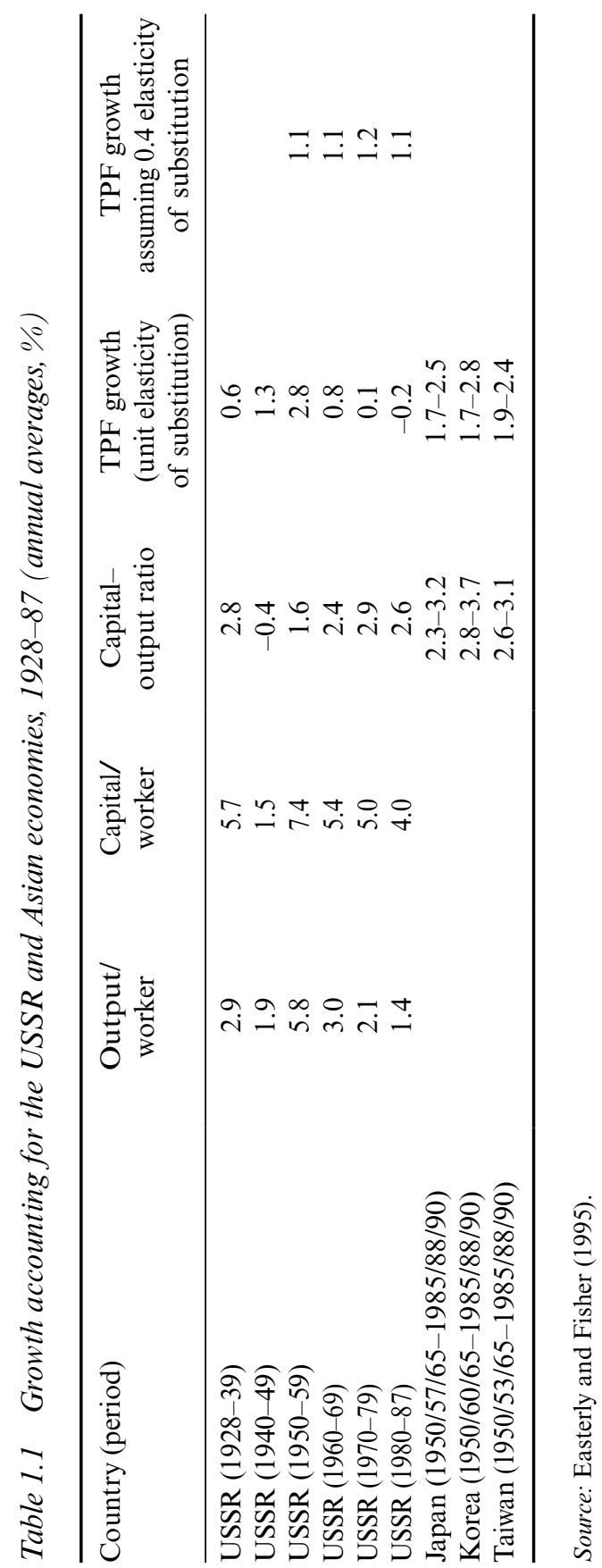




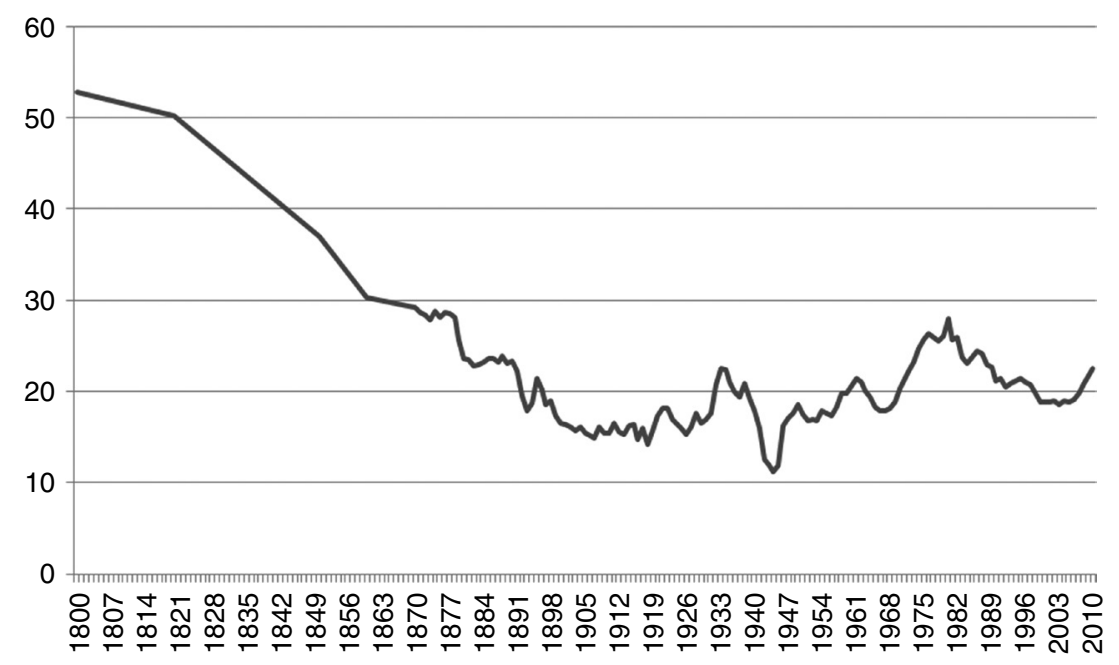

Source: Maddison Project (2013).

Figure 1.6 PPP GDP per capita in Brazil as a percentage of US level, $1800-2010$

incomes between 10 percent to 40 percent of the US level before the Second World War, joining the rich countries' ranks in the second half of the twentieth century - Japan, Hong Kong, Singapore, Taiwan and South Korea in chronological order (Figure 1.7). The Hong Kong and Singapore cases involve cities with populations of several million people, while the other three are indisputable cases of successful catch-up development.

As with the Marshall Plan in Western Europe from the late 1940s, rapid post-war growth in Japan, South Korea and Taiwan was helped by the US interest in preventing the spread of communism in Asia. It provided unprecedented aid as well as policy and fiscal space that played a crucial role in accelerating economic growth and structural transformation in these countries. With China accelerating growth and structural transformation in the 1950s, Malaysia, Thailand and Indonesia followed in the 1960s and 1970s, with Vietnam following later (Figure 1.8) with gradual 'Chinese-style' market-oriented reforms from the mid 1980s.

Such post-war growth accelerations were not unique to East Asia, including countries as varied as Botswana and Lesotho in sub-Saharan Africa, India and Sri Lanka in South Asia, Israel, Oman and Tunisia in the Middle East and North Africa (Figure 1.9). In Europe, rapid growth was observed in Greece, Ireland, Montenegro, Portugal and Spain (Table 1.2). While no developing countries outside East Asia have achieved per capita income of 


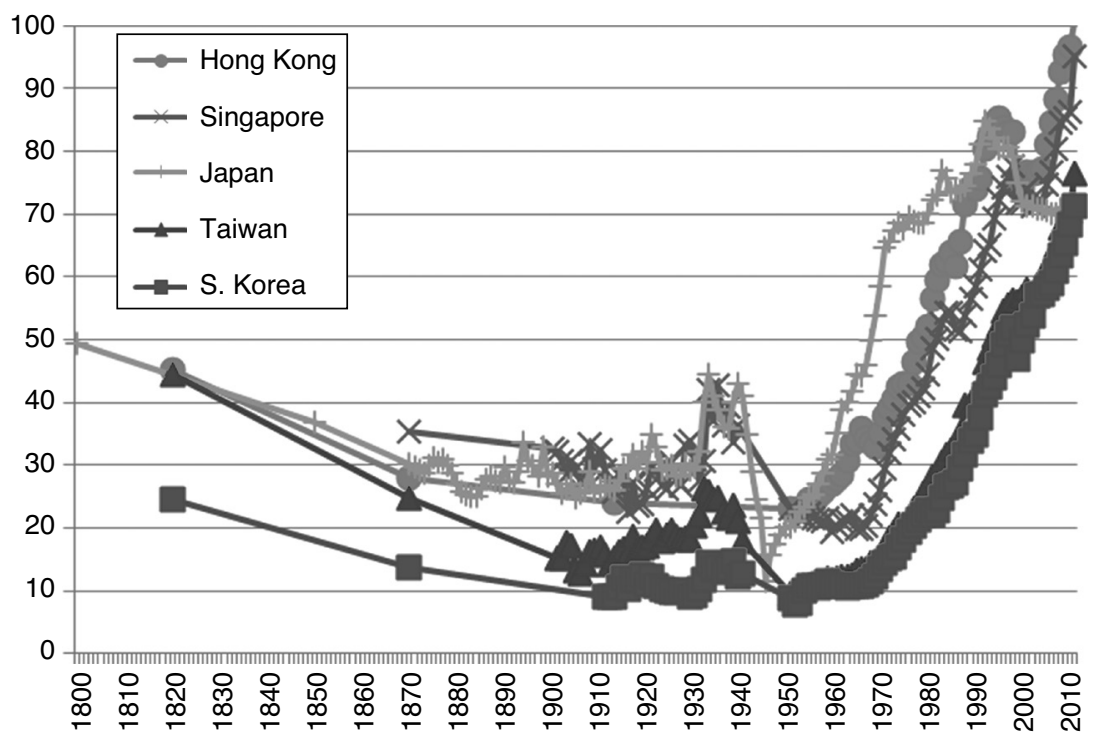

Source: Maddison Project (2013).

Figure 1.7 PPP GDP per capita in countries/territories that took off after the Second World War (Japan, Taiwan, Hong Kong, Singapore, South Korea)

over 50 percent of the US level, the gap in levels of economic development between the Rest and the West has stopped widening, and arguably been reversed, especially with the developed country slowdown following the 2008 financial crisis and the commodity price boom until 2014.

\section{THE SOUTH AND THE WEST IN 2060}

There are predictions that due to poor governance, corruption and lack of structural reforms, growth in emerging economies will slow down compared to the 2000-12 period when growth was untypically high (Åslund, 2013). But most predictions have been based on assumptions that particular growth-oriented policies will or will not be enacted.

Imagine, for a moment, a debate about future economic miracles in 1960: some would have bet on more free, democratic and entrepreneurial India and Latin America, while others would have envisioned the success of authoritarian (sometimes even communist), centralized and heavyhanded government interventionist East Asia. Today, the conventional 

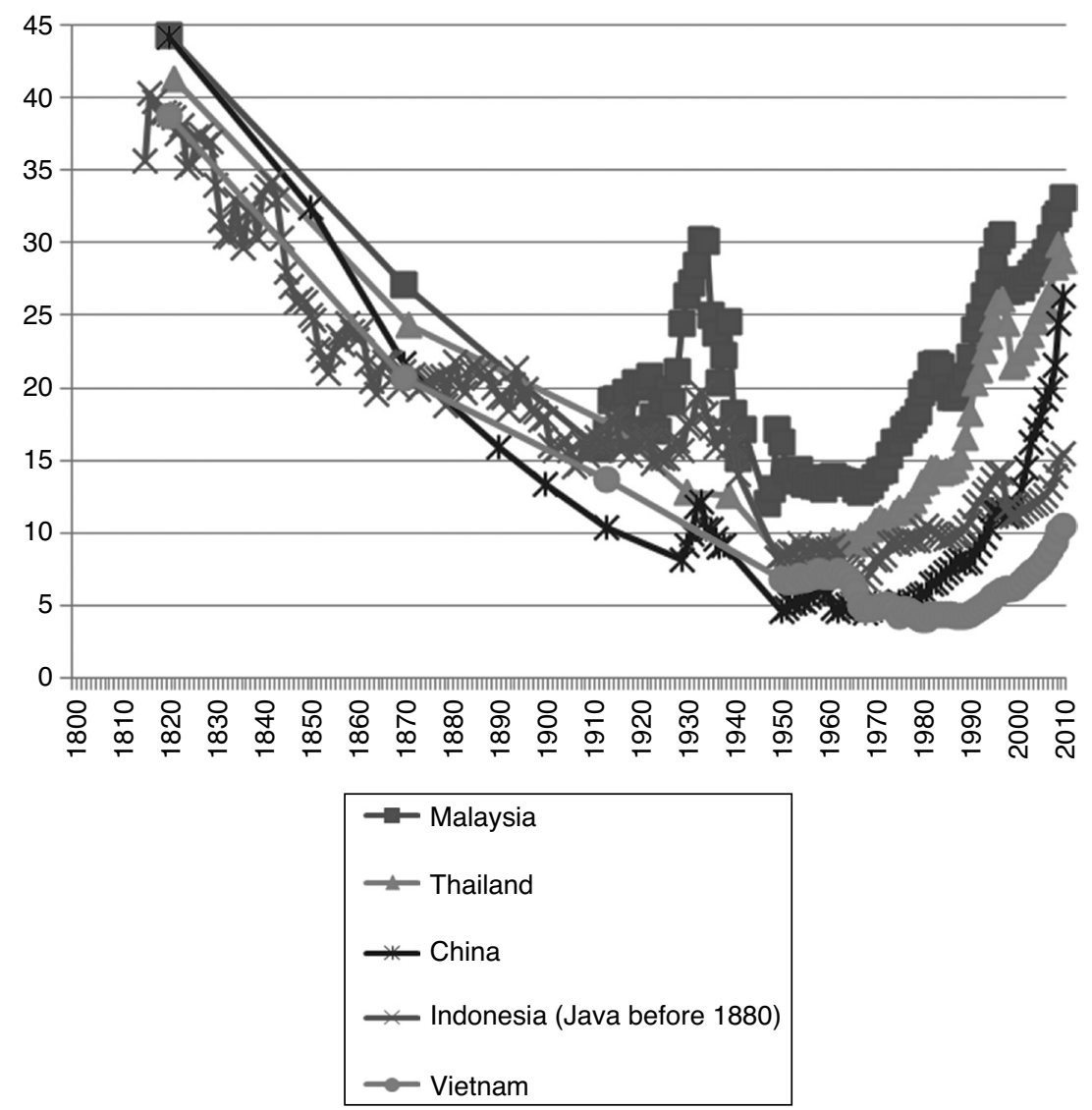

Source: Maddison Project (2013).

Figure 1.8 PPP GDP per capita in countries that took off in the 1960s and later (Southeast Asia, China)

wisdom seems to point to democratic countries encouraging individual freedoms and entrepreneurship, like Mexico and Brazil, Turkey and India, as those with future growth acceleration prospects, whereas currently authoritarian, rapidly growing regimes, like China and Vietnam, are thought to be doomed to experience growth slowdowns, if not recessions, in the near future. But conventional wisdom predictions today could prove to be wrong, as they did in the past.

If the growth rates of the recent half century (1960-2010) continue for another 50 years (2010-60), the world would look very different 


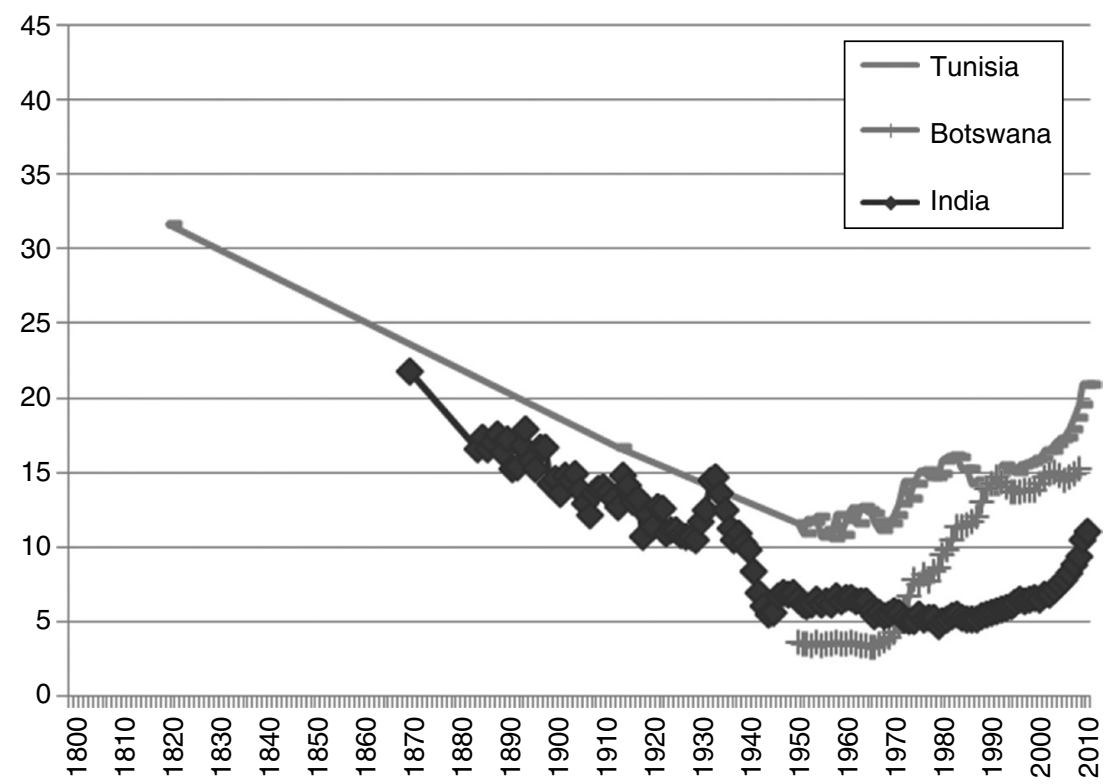

Source: Maddison Project (2013).

Figure 1.9 PPP GDP per capita in India, Tunisia, Botswana

(Figure 1.10) - China and Japan would have higher GDP per capita than the USA (if their population is five times larger, their total GDP will be six times higher than the US GDP). If other countries like India catch up with the West, Europe, Japan and the USA together would account for less than 20 percent of world output.

The rise of Asia, especially China, is usually discussed in geopolitical terms - new superpowers, multipolar versus unipolar world, changing global leadership - or in terms of increasing demand for global resources and contribution to global pollution and warming. But there are other, no less important, albeit less expected and less visible consequences of the rise of East and South Asia.

First, the rise of China, if it continues, would become a turning point for the world economy because for the first time in history, successful economic development on a major scale would be based on an indigenous, not a Western-type, economic model. Because China was so successful in catch-up development, it is no surprise that it has become extremely appealing to the developing world. The attractiveness of the recent Chinese economic growth experience could be compared with 
Table 1.2 Fastest growing countries: average annual per capita real GDP growth rates, $1950-2013(\%)$

\begin{tabular}{lccc}
\hline Country (period) & $\begin{array}{c}\text { Growth rate, } \\
1950-\end{array}$ & $\begin{array}{c}\text { Growth rate, } \\
1960-\end{array}$ & $\begin{array}{c}\text { Growth rate, } \\
\text { 1960-2013 (WDI) }\end{array}$ \\
\hline Taiwan & (Maddison) & 2010 (Maddison) & \\
S. Korea & 5.5 & 5.9 & \\
China & 5.5 & 5.9 & 6.0 \\
Oman & 4.9 & 5.1 & 6.6 \\
Hong Kong SAR, China & 4.7 & 4.8 & 6.5 \\
Botswana (Maddison data & 4.5 & 4.7 & 4.2 \\
$\quad$ until 2008) & 4.5 & 5.1 & 5.7 \\
Singapore & 4.4 & & \\
Thailand & 4.2 & 5.2 & 5.2 \\
Japan & 4.1 & 4.4 & 4.4 \\
Burma (Myanmar) & 3.8 & 3.5 & 3.2 \\
Spain & 3.5 & 3.8 & $2.8(1960-2004)$ \\
Greece & 3.5 & 3.1 & 2.7 \\
Portugal & 3.3 & 3.2 & 2.3 \\
Israel & 3.3 & 2.9 & 3.0 \\
Austria & 3.2 & 2.7 & 3.0 \\
Malaysia & 3.2 & 3.8 & 2.6 \\
Ireland & 3.1 & 3.3 & 3.8 \\
India & 2.9 & 3.0 & $3.1(1971-2013)$ \\
Indonesia & 3.0 & 3.1 & 3.1 \\
Tunisia & 3.0 & 3.2 & 2.9 \\
Montenegro & 2.9 & 3.2 & 3.1 \\
Lesotho (until 2008) & 2.5 & 2.9 & 3.4 \\
Sri Lanka & & 2.9 & \\
\hline
\end{tabular}

Sources: Maddison Project (2013); World Development Indicators (WDI) database.

the popularity of the Soviet catch-up development model to the 'Third World' in the 1960s. Even though the Soviet model collapsed, the Chinese model has become heir to the Soviet model in this regard. While it is no longer a centrally planned economy, it is by no means the model of the private, liberal market economy recommended by the Washington Consensus.

For the last three decades, the rise of East Asia, and especially China more recently, has made some (state) interventionist or dirigiste model of catch-up development attractive. Not all developing countries have the same institutional capacities and capabilities as China - necessary 


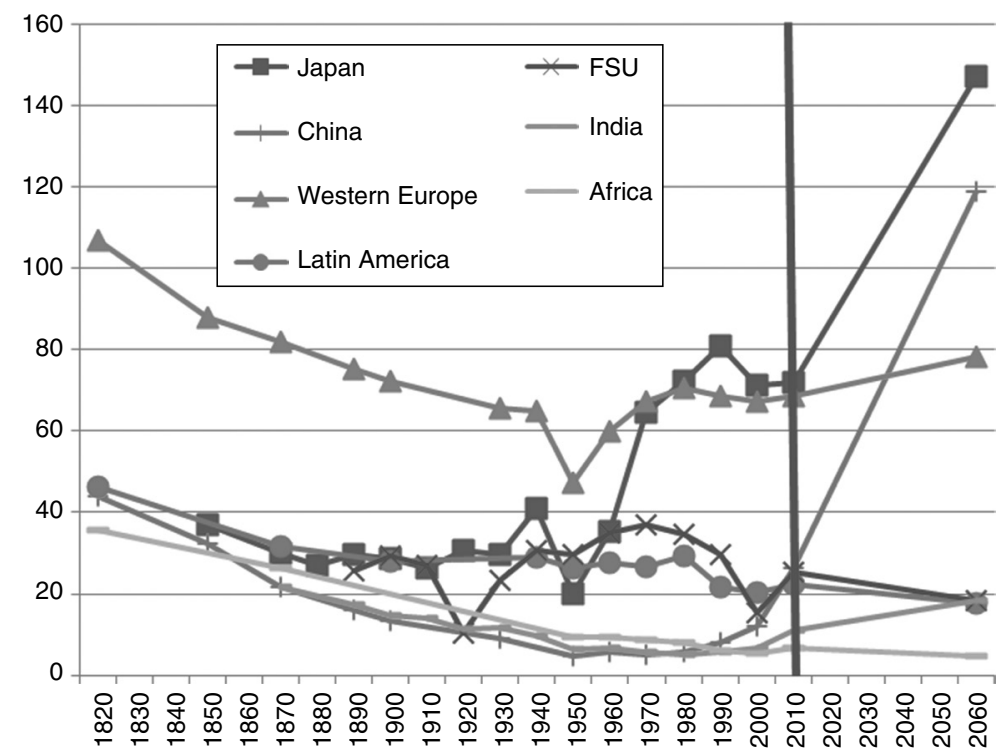

Note: $\mathrm{FSU}=$ Former Soviet Union .

Source: Maddison Project (2013).

Figure 1.10 PPP GDP per capita as a percentage of US level (2060 scenario, assuming continuation of 1960-2010 growth during 2010-60)

components of successful non-Western growth models. But many do, and those that do not may eventually be compelled by circumstances to strengthen institutional and learning capacities and capabilities.

Despite the considerable increase in income inequalities in China after 1985 (Gini coefficients rising), ${ }^{1}$ the level of its inequalities may still be considered tolerable given the size of the country's population. ${ }^{2}$

1 Previously, the Chinese National Bureau of Statistics (NBS) conducted separate household surveys for rural and urban areas, so the Gini coefficients for the whole country were computed by researchers based on certain assumptions about rural-urban income disparities. By December 2012, the NBS had collected data for samples of 140000 urban and rural households from 31 provinces, autonomous regions and municipalities. The NBS set up a new sample system and began to sample 400000 households starting from 1 December 2012 (Zhao Qian, NBS reveals Gini coefficient methods. Global Times, 4 February 2013). According to this nationwide household survey, the Gini index in China was 47-49 percent in 2003-12.

2 It is important to take into account the size of the country - in terms of both territory and population. Three Chinese provinces (Guangdong, Shandong, Henan) have populations of over 95 million, another seven have over 50 million, that is, bigger than most states, so China should be compared with multistate regions, like the USA, India, European Union or 
In the twentieth century, the growth of income differentiation within countries was held back by checks and constraints such as socialist and populist ideologies, social protection and welfare programs. In the twenty-first century, the rise of competitive, low inequality collectivist economic models in the global South may reverse the trend toward rising inequalities since the 1980s, after the Soviet system lost its dynamism and influence and with the Thatcher-Reagan counter-revolution, reflected by the Washington Consensus.

Second, although not nascent so far, the rise of China can trigger profound reforms to international financial and economic relations. Exchange rate undervaluation through accumulation of foreign exchange reserves, export-oriented industrial policy, prudential management of international capital flows and other heterodox measures can become more legitimate tools for catch-up development. There may be reforms to intellectual property rights to facilitate affordable technology transfers, new regulations for the international trade in energy and resources, new monetary arrangements, new agreements for cutting undesirable emissions and so on (Montes and Popov, 2011).

As the economic strength of the South has grown in recent decades (Figure 1.10), it has pushed and will push for changes in international economic relations more conducive to its catch-up development aspirations (Arrighi, 2007). The result may be more favorable conditions for catch-up development of all countries in the South and lower disparities between the world's 'rich' and 'poor.'

A new international economic order, the popular demand of the South in the 1970s, may be back on the agenda of North-South negotiations with the creation of new developing country institutions (BRICS' New Development Bank, Asian Infrastructure Investment Bank). Democratization of international economic relations - that is, adoption of rules-of-the-game giving greater voice and weight to the South together with acceleration of growth in the developing world - has the potential to make globalization 'good for the poor.'

If this interpretation of recent development trends is correct, the next region of successful catch-up development may well be South Asia and

Association of Southeast Asian Nations (ASEAN), rather than with particular states. In the EU 27, for instance, the coefficient of income inequality around 2005 was about 40 percent, with 23 percentage points coming from inter-country inequalities. In China ( 29 provinces), it was over 40 percent, with 24 percentage points due to inter-province disparities. In the USA, the inequality coefficient was similar (over 40 percent), but only six percentage points were due to income disparities among states (Milanovic, 2012). If China manages to reduce income inequalities among its provinces (and among the European Union countries) to a level close to the disparities among US states, overall inequality among citizens would fall significantly. 
other regions willing to draw lessons from East Asian experiences as most appropriate to their own circumstances. The former Soviet Union, Latin America, sub-Saharan Africa and even the rest of Asia can eventually catch up and the global South would come closer to the West in terms of productivity and per capita income.

\section{REFERENCES}

Amsden, Alice (2011). The Rise of 'The Rest'. Challenges to the West from Late-industrializing Economies. New York: Oxford University Press.

Arrighi, Giovanni (2007). Adam Smith in Beijing: Lineages of the Twenty-first Century. London: Verso.

Åslund, Anders (2013). Why growth in emerging economies is likely to fall. Working Paper, Peterson Institute for International Economics, November, Washington, DC.

Easterly, William and Stanley Fisher (1995). The Soviet economic decline. The World Bank Economic Review, 9 (3), 341-71.

Lin, Justin (2012). The Quest for Prosperity: How Developing Economies Can Take Off. Princeton, NJ: Princeton University Press.

Maddison Project (2013). The Maddison Project. www.ggdc.net/maddison/maddi son-project/home.htm (accessed 13 February 2017).

Maurer, Rainer (1995). OLS-estimation of conditional and unconditional sigmaand beta-convergence of per capita income: implications of Solow-Swan and Ramsey-Cass models. Kiel Working Paper No. 698, Kiel Institute for the World Economy.

Milanovic, Branko (2009). Global inequality recalculated: the effect of new 2005 PPP estimates on global inequality. MPRA Paper No. 16538, University Library of Munich, Munich.

Milanovic, Branko (2012). Does economic inequality set the limits to EU expansion? Paper presented at the Conference on Sovereign Insolvency, November, Opatija.

Montes, Manuel and Vladimir Popov (2011). Bridging the gap: a new world economic order for development. In Craig Calhoun and Georgi Derlugian (eds), Aftermath. New Global Economic Order. New York: SUNY Press, pp. 119-48.

Nayyar, Deepak (ed.) (2013). Catch Up: Developing Countries in the World Economy. New Delhi: Oxford University Press.

Ocampo, J.A., J.K. Sundaram and Rob Vos (2007). Explaining growth divergences. In J.A. Ocampo and J.K. Sundaram (eds), Growth Divergences. Explaining Differences in Economic Performance. Hyderabad: Orient Longman, pp. 10-33.

Popov, Vladimir (2007). Life cycle of the centrally planned economy: why Soviet growth rates peaked in the 1950s. In Saul Estrin, Grzegorz Kolodko and Milica Uvalic (eds), Transition and Beyond. Basingstoke: Palgrave Macmillan, pp. 35-57.

Popov, Vladimir (2014). Mixed Fortunes: An Economic History of China, Russia and the West. New York: Oxford University Press.

Sundaram, J.K., with Chen Yun Chung, Brian C. Folk, Irfan ul-Haque, Pasuk Phongpaichit, Batara Simatupang and Mayuri Tateishi (1997). Southeast Asia's Misunderstood Miracle: Industrial Policy and Economic Development in Thailand, Malaysia and Indonesia. Boulder: Westview. 
Sundaram, J.K. and Vladimir Popov (2015). Income inequalities in perspective. ESS Document No. 46, International Labour Office, Geneva, and Initiative for Policy Dialogue (IPD), Columbia University, New York.

Wade, Robert H. (2004). Is globalization reducing poverty and inequality? World Development, 32 (4), 567-89.

WDI database (2010). World Bank, Washington, DC.

WESS (2010). World Economic and Social Survey 2010. Retooling Global Development. New York: United Nations.

WESS (2014). World Economic and Social Survey 2014: Reducing Inequality for Sustainable Development. New York: United Nations. www.un.org/en/development/desa/policy/wess/wess_archive/2014wess_overview_en.pdf (accessed 13 February 2017). 